\title{
Conceptual Metaphors in President Muhammadu Buhari's Political Rhetoric
}

\author{
Zubairu Malah $^{1} \&$ Dinyo Shadrach Taiwo ${ }^{2}$ \\ ${ }^{1}$ Department of English, Yobe State University, Damaturu, Nigeria \\ ${ }^{2}$ Umar Suleiman College of Education, Gashua, Yobe State, Nigeria \\ Correspondence: Department of English, Yobe State University, Sir Kashim Ibrahim Road, P.M.B. 1144, \\ Damaturu, Yobe State, Nigeria. Tel: 234-8032-823-390. E-mail: zubayrmalah@yahoo.com
}

Received: October 15, 2020; Accepted: November 4, 2020; Published: November 5, 2020

\begin{abstract}
Conceptual metaphors continue to receive scholarly attention from discourse analysts taking political discourse seriously. Studies are often interested in the versatile discourse functions of metaphors; how political leaders deploy them as powerful weapons in their armory of political oratory. Therefore, this study extends the current knowledge by exploring conceptual metaphors in President Muhammadu Buhari's political rhetoric. It was guided by two major questions: (1) What types of conceptual metaphors does President Muhammadu Buhari deploy in his political rhetoric? and (2) What rhetorical functions do the Conceptual Metaphors deployed in President Muhammadu Buhari's political rhetoric perform? The study's theoretical impetus was Lakoff and Johnson's (1980) Conceptual Metaphor Theory (CMT), and Charteris-Black's (2009) Contemporary Model of Metaphor and Political Communication was also applied in the analysis. The speeches analyzed include: (1) Muhammadu Buhari's Presidential Primaries Speech, (2) Muhammadu Buhari's Acceptance Speech, (3) Muhammadu Buhari's Victory Speech and (4) Muhammadu Buhari's (First) Presidential Inaugural Speech. The results show that President Buhari, in his political rhetoric, mostly uses HUMAN metaphors (32\%), WAR metaphors (21\%) and JOURNEY metaphors (16\%). Moreover, further analysis revealed that Buhari mostly uses conceptual metaphors to establish his ethical integrity, heighten emotional impact and communicate his anti-corruption and political ideologies. The study concluded that conceptual metaphors are vital resources for construction of persuasion in President Muhammadu Buhari's political rhetoric.
\end{abstract}

Keywords: conceptual metaphors, delegitimization, forming legitimacy, ideology, persuasion, political discourse, political rhetoric, president muhammadu buhari

\section{Introduction}

Language has been a fundamental tool in political communication. It interacts with other modes of communication - such as pictures, music, gestures and tone of voice - to facilitate the attainment of political speakers' communicative goals. The central goals of political speeches, argued Wilson (1994), Alimole (2004), CharterisBlack (2005) and Prados and Penuelas (2012), are persuasion and (favorable) impression management. Hence, in their political rhetoric, political leaders typically utilize language strategically to evoke palpable emotions and break down barriers of beliefs, attitudes, views and prejudices and ultimately win the unflinching support and goodwill of their audience. Democratic leaders often manipulate language to persuade their audience that they, their ideas, ideologies and policies can be trusted. Their discourse is deliberately designed to establish their positive virtues, such as credibility, integrity, morality, authority and honesty - self-legitimization. In addition, they also aim to represent their political opponents negatively. They often demonize the opponents, attack them, their ideas, policies and ideologies - delegitimization (Chilton, 2004; Charteris-Black, 2005; Wodak, 2009). They intentionally enact their discourse so that potential followers are ultimately convinced to make favorable decisions based on their judgments of the authority, credibility, honesty and integrity of political aspirants. Therefore, in attempts to achieve these political goals, political leaders characteristically deploy different discourse resources and spoken strategies in their political rhetoric. One of the most vital spoken strategies often employed in political rhetoric is conceptual metaphor (Lakoff and Johnson, 1980; Jeffrey, 1996; Semino, 2008).

The notion of conceptual metaphor is based on the cognitive view on linguistic metaphors initiated by Lakoff and Johnson (1980). It refers to the transference of meanings from one particular domain (A), such as politics or life, to another different domain (B), such as war or journey, - hence POLITICS IS WAR. It is concerned with how 
discourse receivers are made to conceptualize particular concepts/ideas in terms of others; how words/phrases such as the leader or corruption are used with new senses that differ from their usual and more basic senses, such as parent or enemy - as in THE LEADER IS A PARENT and CORRUPTION IS AN ENEMY. (Lakoff and Johnson, 1980; Kovecses, 2002). These cross-domain mappings and shifts in meanings give conceptual metaphors both cognitive and affective appeals. They give metaphors subliminal influence that arouses emotional responses from the audience. Thus, cognitive linguists posit that what matters most about these metaphors is not their 'accidental' linguistic form but their subliminal influence and emotional potential which contribute to persuasion and the performance of leadership. The scholars contend that these spoken strategies typically affect thought and action; that they appeal to different emotions, and their versatile functions make them central in political communication (Lakoff and Johnson 1980; Musolff, 2004; Charteris-Black, 2005).

Moreover, for their versatile discourse functions, conceptual metaphors continue to receive scholarly attention not only from (cognitive) linguists but also from psychologists and philosophers (Musolff, 2004; Moser, 2000). From the field of psychology, for instance, studies focusing on metaphor include Verbrugge and McCarrell (1977), McGlone (1996) and Bornstein and Becker-matero (2011). In the field of linguistics, metaphor studies have been a prolific area of tremendous advances, especially among scholars interested in political discourse. This category of researchers has consistently reported that conceptual metaphors interact with political leaders' ideologies, charisma, design of leadership style, success and power (see, for example, Charteris-Black, 2005; Mio et. al., 2005; Lu and Ahrens, 2008; Charteris-Black, 2009). They argue that metaphors are being utilized by political leaders for the construction of social and political realities, for vivid conveyance of messages on abstract and complicated political issues for their audience to cognitively access, consciously and unconsciously.

In the light of the vital roles of metaphors in political rhetoric, Charteris-Black (2009) employed an empirical approach to establish that the Aristotelian model of rhetoric $(1991,1996)$ needs to be modified to better suit the analysis of contemporary political discourse. The Aristotle's classical model of rhetoric has three major components: Ethos, Logos and Pathos. Ethos is how a speaker takes a stance that is morally and ethically worthy to enhance his/her credibility among the audience; Logos refers to how the speaker appeals to audience's reason by presenting evidences to back his/her arguments; and Pathos is how the speaker is able to arouse the audience's emotions. Charteris-Black observes that the Aristotle's model has not taken cognizance of myth and ideology of political discourse producers. Therefore, the scholar analyzed Fidel Castro's and Tony Blair's metaphor uses and subsequently argues that the Aristotelian model should be modified to accommodate ideology and myth, which are both very much related to contemporary politicians' use of conceptual metaphors. He observes that metaphors are central in verbalizing ideology and myth in political discourse.

Charteris-Black's (2009) proposed model provides a more comprehensive and explanatory account of metaphor in political communication. It comprises four major components: (1) Metaphors that Establish Ethical Integrity, (2) Metaphors that Communicate Political Arguments and Policies, (3) Metaphors that Heighten Emotional Impact, and (4) Metaphors that Communicate Ideology and Political Myth (for details, see 3.4 below). It is, therefore, agreeable that this model is more comprehensive for the analysis of conceptual metaphors in political discourse. Thus, while previous studies on metaphors uses by previous Nigeria's presidents mostly applied other models (see, for example, Kamalu and Iniworikabo, 2016; Aremu, 2017), the current study applies CharterisBlack's (2009) model to President Muhammadu Buhari's metaphor use. This attempt could yield more findings and consequently broaden the existing knowledge on the use of conceptual metaphors as rhetorical tools among political leaders.

In addition, despite the tremendous advancement in conceptual metaphor research, the literature still suggests that utilization of conceptual metaphors among Nigerian democratic Presidents has received scant scholarly attention. Little is known about how Nigeria's Presidents utilize conceptual metaphors in their political rhetoric. The current study, therefore, was an endeavor to extend the current knowledge by exploring how President Buhari utilizes conceptual metaphors in his political rhetoric. The study was guided by the following research questions:

I. What types of Conceptual Metaphors does President Muhammadu Buhari deploy in his political rhetoric?

II. What rhetorical functions do the Conceptual Metaphors deployed in President Muhammadu Buhari's political rhetoric perform?

\subsection{President Muhammadu Buhari}

Muhammadu Buhari has been Nigeria's current democratically elected President (2020). He was sworn in on Friday, the $29^{\text {th }}$ of May, 2015. He contested under the All Progressives Congress (APC) party; a party formed as a result of merger of Nigeria's opposition political parties in a move to defeat the then incumbent government. He is a retired Major General who also served as Nigeria's Head of State from $31^{\text {st }}$ December 1983 to $27^{\text {th }}$ August 
1985. As a result of his earlier achievements in office, President Buhari has been a charismatic and highly respected figure in Nigeria. He has made his mark globally for honesty and fierce fight against corrupt practices and indiscipline in the Nigerian society. His victory at the APC primaries resulted in political renaissance that revolutionized Nigerians' approach to politics.

President Buhari's popularity does not only derive from his renowned credibility, honesty, patriotism and solemn anti-graft stance. His popularity also has much to do with his oratory skills that enable him to always emotionally move his audience. These are among the critical reasons that enabled him to propagate the need for CHANGE in Nigeria's presidency during his campaigns. These qualities made Buhari eventually succeed in defeating the then incumbent president Goodluck Jonathan, who also contested for the presidency under the People's Democratic Party (PDP). This is the first time in Nigeria's history that an incumbent president lost to an opposition candidate (Malah and Idris, 2016).

\subsection{Background to President Buhari's Speeches Analyzed}

This study analyzed four speeches of President Muhammadu Buhari delivered at different times, addressed to different target recipients, for different purposes, in his political career. These speeches include: (1) Muhammadu Buhari's Presidential Primaries Speech, (2) Muhammadu Buhari's Acceptance Speech, (3) Muhammadu Buhari's Victory Speech and (4) Muhammadu Buhari's (First) Presidential Inaugural Speech. These speeches are described briefly below:

\subsubsection{Muhammadu Buhari's Presidential Primaries Speech}

President Buhari delivered this speech, on $10^{\text {th }}$ December, 2014, during the All Progressives Congress (APC) party's national convention held at the Teslim Balogun Stadium, Lagos. The address was given just before the commencement of the party's Primary Elections, and Buhari spoke as one of the five (5) aspirants vying for the office of the President, Federal Republic of Nigeria. His speech was addressed to the APC delegates - about 8000 - who convened from Nigeria's 36 states and the Federal Capital Territory (FCT) to cast votes and finally decide the party's presidential candidate for the forthcoming general elections in 2015.

In this address, President Buhari enacted his discourse to persuade the audience that he was the best aspirant who had the most required competence to bring about the desired change Nigeria needed at the moment. At the time of this speech, Nigeria was in one of her darkest days in history. The country was under the grip of enormous crises - insecurity, bad economy, unemployment, poverty, corruption, indiscipline, frequent power outages and a dark future. The president, therefore, deployed different rhetorical tools to enable him appeal to the different emotions of the audience and consequently to win their confidence, support and goodwill.

\subsubsection{Muhammadu Buhari's Acceptance Speech}

President Buhari delivered this speech on $11^{\text {th }}$ December, 2014, during the All Progressives Congress (APC) party's convention at the Teslim Balogun Stadium, Lagos. He gave this address just after the completion of the party's Primary Elections and his emergence as the winner. The speech was addressed to the APC party stakeholders, especially the national delegates from the 36 states and the FCT, who had just voted for him to represent the party as its presidential candidate for the forthcoming 2015 general elections in Nigeria.

In this address, President Buhari spoke not only as someone who wished to express acceptance or appreciation, but also as someone who desired to additionally woo the audience's firm confidence and unflinching support. Consequently, the president intentionally designed his discourse to create the impression that the delegates had made the best choice. He tried to arouse, among the audience, the feelings that he took himself seriously, that he took the opportunity seriously, and that he took all Nigerians seriously. His major theme in the speech was, therefore, 'rebuilding Nigeria'. He persuaded the audience that he was determined to take Nigeria out of the 'dark days' - of insecurity, bad economy, unemployment, poverty, corruption, indiscipline, power outage and a dark future. This was achieved through the use of carefully harnessed rhetorical devices by the president in the speech.

\subsubsection{Muhammadu Buhari's Victory Speech}

President Muhammadu Buhari delivered his Victory Speech on the $1^{\text {st }}$ of April, 2015. It immediately followed the official announcement of his victory as the newly elected president of the Federal Republic of Nigeria by Nigeria's Independent National Electoral Commission (INEC). The speech was addressed not only to his supporters but also to all Nigerians, African leaders and world leaders.

In this speech, the President-elect's tone was not only appreciative and celebratory but also sorrowful, reflective and reassuring. He appealed to different emotions of the audience and this strategy contributed to the success of the speech, as tones contribute to persuasion (Malah, 2016). He begins by expressing appreciation to God and all 
Nigerians, including those who lost their lives and property during campaign, elections and celebrations, in their contributions to his victory. He then urged Nigerians to celebrate calmly to avoid further loss of lives and property. He implores Nigerians to 'forget old battles and past grievances and forge ahead and be united' for the good of the country. He promises to serve Nigerians justly and without bias - no Nigerian shall be discriminated against for any reason. He appreciates his party APC and also 'extends a hand of friendship and conciliation' to the opposition and emphasizes that he had no ill will against anyone.

President Buhari also salutes Nigeria's foreign friends in Africa and other continents. These include ECOWAS, President Obama, the EU, the UK, France, Germany, China, and India for their contributions to the success of the elections. He pledges to work with them in confronting issues of global concern-terrorism, drug-related offences, climate change, diseases etc.

Finally, Buhari also commends Nigeria's former presidents for their statesmanship and peace-building measures during the campaigns and elections. He pledges to tackle Nigeria's most pressing challenges - insurgency, corruption, insecurity, economic crisis - very seriously and implores Nigerians to join him in this task. He concludes by promising to do his utmost to 'bring the Nigeria Nigerians seek'.

\subsubsection{Muhammadu Buhari’s (First) Presidential Inaugural Speech}

President Muhammadu Buhari delivered his (first) Inaugural Address on the $29^{\text {th }}$ of May, 2015, at the Eagle Square, in Abuja, Nigeria. He had just been sworn in as the new President of the Federal Republic of Nigeria, and this address formally marked the commencement of his tenure of office. The new president presented his debut speech not only to APC partisans, delegates or his supporters; the speech was intentionally designed to all Nigerians generally, irrespective of party affiliations, prejudices, views and other differences.

Given the prevalent challenges and precarious situation in Nigeria, Buhari's inaugural address did not focus only on appreciating and acknowledging the electorate's mandate. His tone was not only celebratory. The president employed multiple tones and this contributed to the emotional and persuasive impact of the speech (Malah, 2016). The discourse was markedly epideictic and encouraging, full of 'assertives' and 'commissive' speech acts. The president outlined the agenda of his administration under the 'change' maxim. He promised to fully uphold Nigeria's constitutional principles and tenets of democracy. He pledged firm determination and fairness in tackling the country's current predicaments. Specifically, the new president pledged to bring Nigeria back to the right track set by the founding fathers. He enumerated the most bedeviling challenges of the country - insecurity, economic crisis, youth unemployment, power shortages, communal clashes, armed robberies, and promised to face them head-on.

Finally, the president preached patriotism, unity and hard work among Nigerians. He enacted his discourse to break down the barriers of interests, views, beliefs and prejudices among Nigerians and charged them to get united and work together for the good of the country. He implored Nigerians to take advantage of the current global respect, cooperation and goodwill smiles Nigeria was enjoying at the moment to work hard towards the country's prosperity. He then bade Nigerians that it was time to bring about change in the state of the nation.

\subsection{Theoretical Framework}

This study draws on George Lakoff and Mark Johnson's Conceptual Metaphor Theory (1980). This theory has been the impetus of the School of Cognitive Metaphor analysis, founded by Lakoff and Johnson with the seminal publication of their Metaphors We Live By in 1980. In this theory, conceptual metaphor is defined as the phenomenon whereby discourse producers (and receivers) talk and think about something in terms of something else, how they explain (or understand) one conceptual domain (A) in terms of another conceptual domain (B). Therefore, words and phrases become metaphoric when they are contextually used with new senses that are conditioned by rhetorical aims of communicators. When this happens, the conceptual domain (B) such as war, journey and family, which facilitates the conceptualization of domain (A), is termed source domain; while the conceptual domain (A) such as politics, life and the leader, which is conceptualized in terms of (B), is termed target domain (Lakoff and Johnson, 1980; Kovecses, 2002).

Moreover, Lakoff and Johnson (1980) argue that metaphors are pervasive in our everyday life, and they play key roles in the construction of social and political realities. They add that the most significant properties of metaphors are their cognitive, conceptual and subliminal potentials, not their linguistic shape. Thus, discourse analysts often draw on this theory to investigate the versatile discourse functions of conceptual metaphors in different types of discourses and genres - political, scientific, literary, business and so on. Specifically, researchers interested in political discourse often investigate the rhetorical functions of conceptual metaphors, how the use of metaphors among political leaders contribute to persuasion, authority, and forming legitimacy (see, for example, Musolff, 
2004; Charteris-Black, 2005; Lu and Ahrens, 2008; Kamalu and Iniworikabo, 2016; Aremu, 2017). The current study is therefore an endeavor to contribute to this tradition of research.

\section{Review of Related Studies on Metaphor}

The role of conceptual metaphors in political discourse has been a major concern among scholars. Through the decades, metaphor studies have unraveled fascinating findings from the analysis of political genres performed by democratic leaders. For instance, Mio et al (2005) investigated the interaction between conceptual metaphors and charisma among American presidents - from George Washington to Bill Clinton. The study focused specifically on inaugural addresses. The researchers discovered that charismatic presidents utilized nearly twice the percentage of metaphors in their inaugural rhetoric than the non-charismatic presidents. The study concluded that presidents with positive charisma often utilized metaphors to inspire and motivate their followers. Therefore, Mio's study has broadened our understanding of the rhetorical centrality of metaphors in political discourse. These findings have, to some extent, been supported by Charteris-Black's (2009) findings from his analysis of Fidel Castro's and Tony Blair's speeches, where the researcher similarly observed that metaphor use relates to the politicians' charisma.

While Mio et al (2005) were concerned with the interaction between conceptual metaphors and charisma, Lu and Ahrens (2008) were interested in the interaction between conceptual metaphors and ideology. Specifically, Lu and Ahrens explored the impact of ideology on BUILDING metaphors in presidential speeches in Taiwan. The researchers found that Taiwanese presidents promoting Chinese ideology often used BUILDING metaphors as rhetorical strategies, while those opposing Chinese ideology, such as the Democratic Progressive Party presidents, often avoided BUILDING metaphors but used other types of metaphors. The study concluded that Taiwanese presidents often manipulate BUILDING metaphors as strategies to support their political ideologies. It could be seen that Lu and Ahrens' findings have also been corroborated by Charteris-Black's (2005) and Charteris-Black's (2009) findings that conceptual metaphors enabled the verbalization of British and American politicians, and Fidel Castro's and Tony Blair's political ideologies.

Similar to Mio et al's (2005) study, Xu (2010) was concerned with Conceptual Metaphor in American presidential inaugural speeches. But while Mio et al investigated the relation between conceptual metaphors and charisma, Xu's study specifically focused on journey metaphors, human metaphors, and war metaphors, with the aim of revealing how they rhetorically function in the inaugural discourse. Xu observed that American presidents: (1) use journey metaphors to motivate the American people to keep united and move forward together in pursuance of the desired social goals; (2) use human metaphors to personify some abstract political concepts for the understanding and persuasion of the American people; (3) use war metaphors to encourage the American people that in the worthwhile endeavor of achieving America's desirable social goals, personal sacrifice and fearless physical struggle are always essential and inevitable. In sum, the experiment concluded that conceptual metaphors in the American presidential inaugural speeches generally perform three major functions: simplification, persuasion, and motivation. Observed carefully, Xu's findings have revealed the relation between other properties of political discourse and metaphor, different from charisma and ideology as examined by Mio et al (2005) and Lu and Ahrens (2008) above, respectively. It could, therefore, be understood that metaphor plays numerous roles in political discourse.

In another research on metaphor, Escudero (2011) investigated the use of Conceptual Metaphor in President Obama's inaugural speech. But contrary to Xu's study above, Escudero specifically focused on conceptual metaphors as captivating strategies for persuasive aims. The study examined war metaphors, construction metaphors, and journey metaphors. Results of the study indicated that for their cognitive, pragmatic and linguistic qualities, Obama's metaphors were so captivating to engage the emotions of the audience for persuasive goal. Specifically, the construction and journey metaphors were used to emphasize the idea of reconstruction and hope among the American public. Findings of this study, therefore, corroborate those of $\mathrm{Xu}$ (2010) that reported that American presidents utilize conceptual metaphors to fulfill persuasive intentions.

Focusing on the same discourse community with Escudero (2011), Xue et al (2013) also studied American presidential inaugurals. Xue's study analyzed 20 inaugural speeches in an attempt to identify categories of conceptual metaphors and examined their rhetorical functions in the speeches. The metaphors discovered include journey metaphors, human metaphors, building metaphors, family metaphors, light metaphors and illness metaphors. Rhetorically, these metaphors, whose source domains mostly relate to American daily life and experience, were used as persuasive tools in the speeches. Xue et al. concluded that conceptual metaphors perform filtering, persuasive, motivation, simplification, and bridge function in the American presidential inaugural speeches. Therefore, Xue et al.'s findings have agreed with Xu's (2010) findings that American presidents use 
conceptual metaphors for the purposes of persuasion, simplification and motivation in their speeches. In addition, Xue et al.'s study has revealed more categories of conceptual metaphors used by the American presidents.

While Xue et al. (2013) investigated inaugural speeches of American presidents, Pasaribu (2016) explored the source domains (of conceptual metaphors) in Indonesia's Joko Widodo's Victory and Inaugural speeches. The study found that Widodo, in these speeches, handled the (target) domains of politics in terms of a number of source domains that relate to Indonesians' daily life and experience, namely, unity, war, journey, human character and navigation. The use of these more concrete concepts, Pasaribu argues, facilitated the public's understanding of the more abstract political concepts. The study contends that the use of these metaphors was a powerful strategy in Widodo's rendition because it supported the conveyance of intended political messages that consequently resulted in persuading the audience. Therefore, Pasaribu's findings are consistent with those of Xue et al. (2013) in that the source domains employed relate to the audience's daily life and experience. Similarly, Pasaribu's findings also concur with those of Xu (2010) and Escudero (2011), which also reported that President Obama utilized conceptual metaphors to appeal to the emotions of unity, courage, freedom and hope among the American people.

In the Nigerian context, the use of conceptual metaphors in political discourse is also being researched. Kamalu and Iniworikabo (2016), for example, examined the utilization of conceptual metaphors in the political speeches of Nigerian presidents -Obasanjo, Yar'adua and Jonathan. The research revealed that Nigerian presidents use, for example, WAR, BUILDING, JOURNEY and FAMILY metaphors to not only enhance their rhetoric on Nigeria's nationhood and unity but also to communicate their political ideologies. Ideologies mostly communicated, reported Kamalu and Iniworikabo, include anti-corruption fight, eradication of poverty, and restoration of Nigeria's waning glory. Thus, Kamalu and Iniworikabo's findings agree with those of Xu's that President Obama uses metaphors to preach unity among Americans. Kamalu and Iniworikabo's findings are close to those of Lu and Ahrens (2008) and Charteris-Black's (2009) that revealed metaphors used by political presidents often relate to their political ideologies.

Another study on Nigeria's political rhetoric is Aremu's (2017), which investigated conceptual metaphors in Nigerian presidents' inaugural speeches (1979 to 2015). The study specifically analyzed the pragmatics of crossdomain mappings in the speeches. The researcher discovered that in their debut addresses, Nigerian presidents deploy variety of conceptual mappings such as BATTLE, JOURNEY, BUILDING and FAMILY. These findings agree with those of Kamalu and Iniworikabo (2016) on the dominance of BATTLE, JOURNEY, BUILDING and FAMILY metaphors in the political discourse of Nigerian presidents. However, Kamalu and Iniworikabo additionally reported on the relation between metaphor and political ideologies of the presidents. Aremu argues that these presidents use cross-domain mappings as pragmatic strategies for thanking, appealing, remembering, and promising the audience on varieties of political issues. This difference could have resulted from the research focus adopted in the two studies.

While most studies on conceptual metaphors focus on offline political discourse, Ramanathan et al (2018) studied online political discourse. The study analysed the use of metaphor in the political tweets of the Malaysian Prime Minister Najib Razak and the Indian Prime Minister Najendra Modi during their campaigns. The study discovered that the most dominant conceptual metaphor in the tweets of the two leaders was the ELECTION IS A BUILDING metaphor. The researchers further observed that this broad metaphor has three metaphoric entailments: (1) POLITIANS ARE NATION CONSTRUCTORS, (2) CITIZENS ARE LABOURERS and (3) THE NATION IS AN EDIFICE. It was also reported that the two leaders strategically deploy metaphors in their tweets mainly to encourage civilians to vote for them. This study has, therefore, revealed how politicians utilized metaphors as persuasive tools in their campaign tweets.

Lastly in this review, Linkeviciute (2019) examined the use of conceptual metaphors in President Donald Trump's political speeches in 2018. The study found that President Trump mostly used metaphors to conceptualize politics as WAR, JOURNEY, RACE, CRIME, LOVE and FRIENDSHIP. Linkeviciute's study further observed that, on the one hand, President Trump utilized metaphors to portray himself and his party the Republican as extremely positive and beneficial, who are determined to 'make America great again'. On the other hand, the results from the study also showed that Trump manipulated metaphors to represent his political opponents, the Democrats, negatively, depicting them as enemies of America, responsible for all the troubles the country was facing. Therefore, Linkeviciute's research discovered how President Trump utilized metaphor to attribute positive image to himself and his party, and negative image to his political opponents. These findings have supported Chilton's (2004), Charteris-Black's (2005) and Charteris-Black's (2009) positions that Democratic leaders often manipulate language to persuade the audience members that they, their ideas, ideologies and policies can be trusted; and that they also aim to represent their political opponents negatively. 
In conclusion, based on the brief review thus far, it could be agreeable that scholars researching conceptual metaphors in political discourse mostly focus attention on how metaphors are utilized by political leaders to achieve communicative and persuasive goals. It could also be understood that tremendous advances have been made in this research tradition. However, it appears arguable that the literature still suggests scant scholarly attention on the use of conceptual metaphors by Nigerian democratic Presidents. More needs to be known about how they use metaphors in their political rhetoric. The current study, therefore, is an attempt to explore how President Buhari utilizes conceptual metaphors in his political rhetoric.

\section{Method}

\subsection{Research Approach}

This discourse analysis study was qualitative in approach. The researcher worked with written texts in attempts to form plausible answers to the research questions raised. The methodological decision was guided by Dornyei (2007), Merriam (2009) and Creswell (2012), who have been consistent that a qualitative researcher could be the sole instrument for data collection, data analysis and interpretation of results; his subsequent creative answers to the research questions are also acceptable.

\subsection{Sampling}

The study drew on Merriam (2009), Matthews and Rose (2010), Creswell (2012) and Tavakoli (2012) and applied purposive sampling, where purposive samples were intentionally handpicked by the researcher to enable in-depth exploration of the research questions. The purposive samples were four political speeches of President Muhammadu Buhari - Muhammadu Buhari's Presidential Primaries Speech, Muhammadu Buhari's Acceptance Speech, Muhammadu Buhari's Victory Speech and Muhammadu Buhari's (First) Presidential Inaugural Speech. The purposive samples were based on the criteria that: (1) each of the speeches was delivered by President Muhammadu Buhari to move his audience at different times of his political career; (2) each of the speeches had a different purpose and target audience, and (3) each of the speeches was text-based.

\subsection{Data Collection}

All the texts analyzed in this study were collected online from the websites of Nigerian newspapers. Muhammadu Buhari's Presidential Primaries Speech was collected from Pulse Nigeria, on 11/12/2014, at $\mathrm{http} / /$ pulse.ng/politics/apcdecides-buhari-gives-emotional-speech-at-presidential-primaries-id3340586.html ; Muhammadu Buhari's Acceptance Speech was obtained from Pulse Nigeria, on 12/12/2014, at http://pulse.ng/politics/apcdecides-buhari-gives-emotional-speech-at-presidential-primaries-id3340586.html ; Muhammadu Buhari's Victory Speech was culled from Vanguard Newspaper, on 01/04/2015, at https://www.vanguardngr.com/2015/04/buharis-acceptance-speech/. While Muhammadu Buhari's (First) Presidential Inaugural Speech was obtained from Vanguard Newspaper, on 29/05/2015, at http://www.vanguardngr.com/2015/05/read-president-buhari-inaugural-speech/ .

\subsection{Data Analysis}

In keeping with the two research questions guiding the study [(i) what types of Conceptual Metaphors does President Muhammadu Buhari deploy in his political rhetoric? and (ii) what rhetorical functions do the Conceptual Metaphors deployed in President Muhammadu Buhari's political rhetoric perform? two phases of analysis were conducted. The first phase of analysis focused on identifying the types of conceptual metaphors (or source domains) in the data. In doing this analysis, Lakoff and Johnson's (1980) framework was applied.

The second analysis drew on Charteris-Black's (2009) contemporary model of metaphor and political communication. In this model, Charteris-Black submits that forming legitimacy, the desire to present self as the only legitimate source of power, authority and credibility, is the central goal of political communication, and that in attempts to achieve legitimacy, political orators utilize conceptual metaphors in four broad ways. In other words, the scholar argues that conceptual metaphors perform four major rhetorical functions in political discourse. These four functions are:

I. Metaphors that Establish Ethical Integrity: these are metaphors that rhetorically heighten politician's ethical and moral qualities, and present him/her as a leader with 'the right intentions' (Ethos). Using these metaphors would make a politician morally and ethically acceptable to the audience. For instance, in the data analyzed in the current study, President Buhari, in his Acceptance Speech on $11^{\text {th }}$ December, 2014, says that he has come to 'rebuild Nigeria'. This BUILDING metaphor would inevitably go a long way in conveying the leader's positive image of right intentions to the audience and, therefore, enhance his acceptability.

II. Metaphors that Communicate Political Arguments and Policies: these are metaphors politicians use for the communication of their political policies and arguments ( $\log O S)$. Their aim is to provide cognitively accessible 
means of communicating political policies and provide evidence that support political arguments, so that the orators are perceived to have the power of 'thinking right'. To take an example from the data of the current study, the BUILDING metaphor used by President Buhari (as shown in 'I' above) additionally frames the political argument that the previous administrations have ruined Nigeria. Other metaphors of this category may support verbalization of politician's policies.

III. Metaphors that Heighten Emotional Impact: in a range of political contexts, politicians deploy metaphors for evocation of different emotions (Pathos). Metaphor researchers have drawn attention that the typical emotions aroused by political rhetoricians include, for example, patriotism, unity, hard work, humor, sacrifice, perseverance, hope and so on (see 2.0 above). The ultimate goal is always for the audience to get persuaded that the speaker is 'sounding right'. Therefore, after arousing the desired feelings in his audience, the political orator would certainly be able to persuade them to his advantage. For instance, in the current study data, President Buhari uses WAR metaphor in his Inaugural Speech - attack the problem of youth unemployment frontally - to appeal to his audience that he is the legitimate source of credibility and authority.

IV. Metaphors that communicate Ideology and Political Myth: Charteris-Black argues that conceptual metaphors are both linguistic and cognitive resources for verbalizing ideology in political discourse. Ideology, according to Charteris-Black (2009) and Jones (2012), are specific sets of meanings, beliefs, and assumptions which a particular group of people has about things such as what is right and wrong, good and bad, normal and abnormal, truthful and untruthful. It enables members of social groups - political, religious, etc. - to construct identity and establish self-legitimization based on those shared attributes. For instance, in his Presidential Primaries Speech, President Buhari utilizes WAR metaphor to 'pledge a Battle ... against the dark forces of corruption and despair'. This metaphor vividly echoes Buhari's anti-corruption ideology, the solemn promise for which his party (APC) has been popular.

On the other hand, myth (in the domain of political discourse) refers to explanatory narratives for political issues requiring explanations. These narratives purport to be a set of truths. They engage the attention of the audience through narratives that embody sets of beliefs expressing aspects of the unconscious. Therefore, Charteris-Black argues that conceptual metaphors have the potential to marry conscious and unconscious ideology with less conscious myth and ultimately persuade the audience. An example of myth in political discourse, observed Charteris-Black, is how Martin Luther King used metaphor to mean that he was a Moses who would inevitably liberate African Americans from the oppressors of Egypt.

Finally, it is well to point out here that in this model a single metaphor can perform multiple but interacting rhetorical functions. It may be, for instance, establishing the politician's ethical integrity on one hand, and also communicating political arguments on the other. It may appeal to ethos, logos, pathos and also creating myth and communicating ideology. To take an example from the present study's data, it has been shown how President Buhari's BUILDING metaphor was used to establish his ethical integrity and also communicate political argument that the previous governments have ruined the nation. The main goal is for the metaphor(s) to ultimately enable the political leader form legitimacy. Figure 3.1 below represents this model graphically:

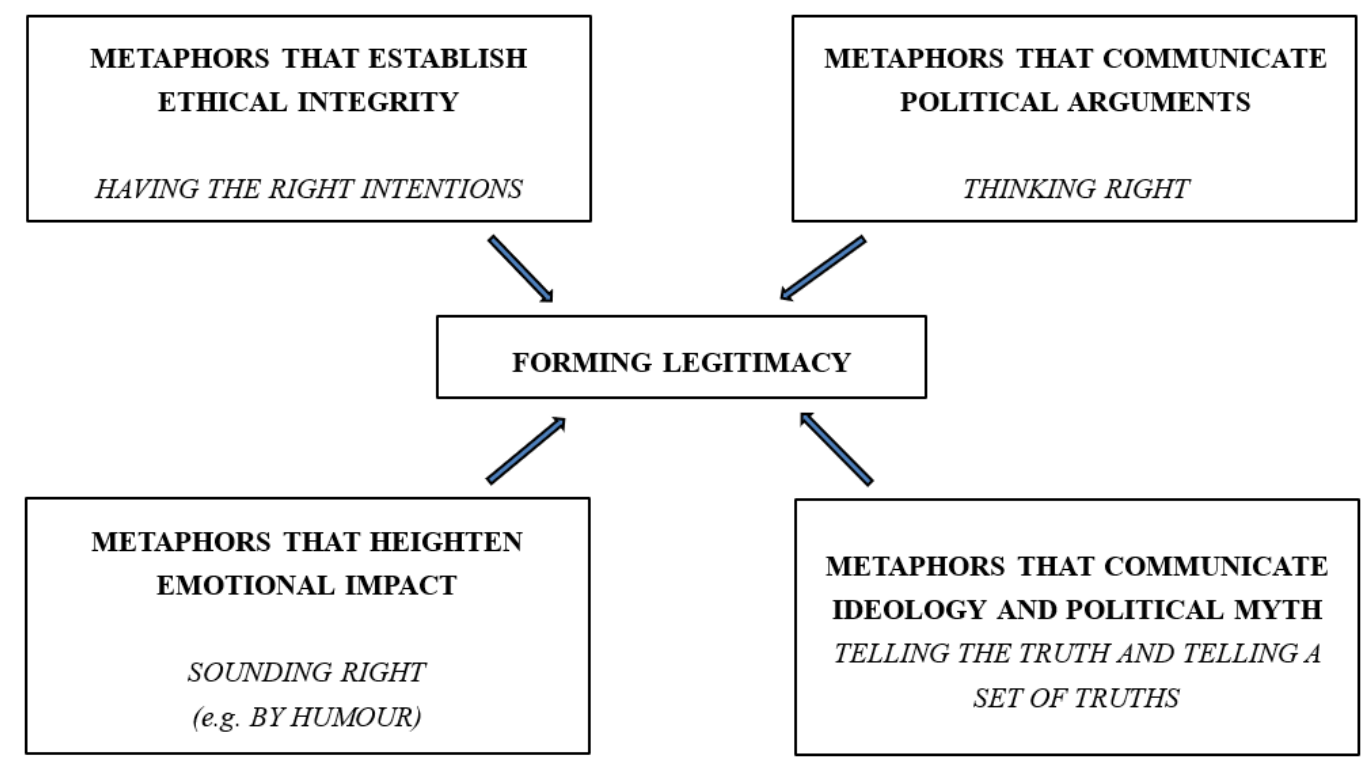

Figure 3.1 Charteris-Black’s (2009) Contemporary Model of Metaphor and Political Communication 


\section{Results and Discussion}

\subsection{Types of Conceptual Metaphors President Muhammadu Buhari Deploys in His Political Rhetoric}

Results from the analysis indicate, on the one hand, that President Muhammadu Buhari, in his political rhetoric, mostly uses HUMAN metaphors ( $32 \%$, see examples 1 to 3 below), WAR metaphors ( $21 \%$, see examples 4 to 6 below) and JOURNEY metaphors (16\%, see examples 7 to 9 below). The president mostly personifies political phenomena and expresses them in human terms for his audience to vividly understand his messages and be ultimately persuaded. He also uses words and phrases from the domain of war/conflict in talking about political issues, perhaps due to his military background. His frequent use of Journey metaphors could be a result of the president's desire to emphasize that the merger of different opposition parties that formed the APC party and the electioneering embarked upon are as inherently purposeful as journeys themselves. So, these dominant source domains could all be explained.

On the other hand, the results also show that President Buhari rarely uses FAMILY metaphors (11\%), BUILDING metaphors (11\%), ILLNESS metaphors (3\%), LIGHT metaphors (3\%) and STORY metaphors (3\%). This could have resulted from Buhari's cultural norms or genre constraints that favor specific types of metaphor than others. Figure 4.1 below represents these findings graphically:

\section{Conceptual Metaphors in President Buhari's Political Rhetoric}

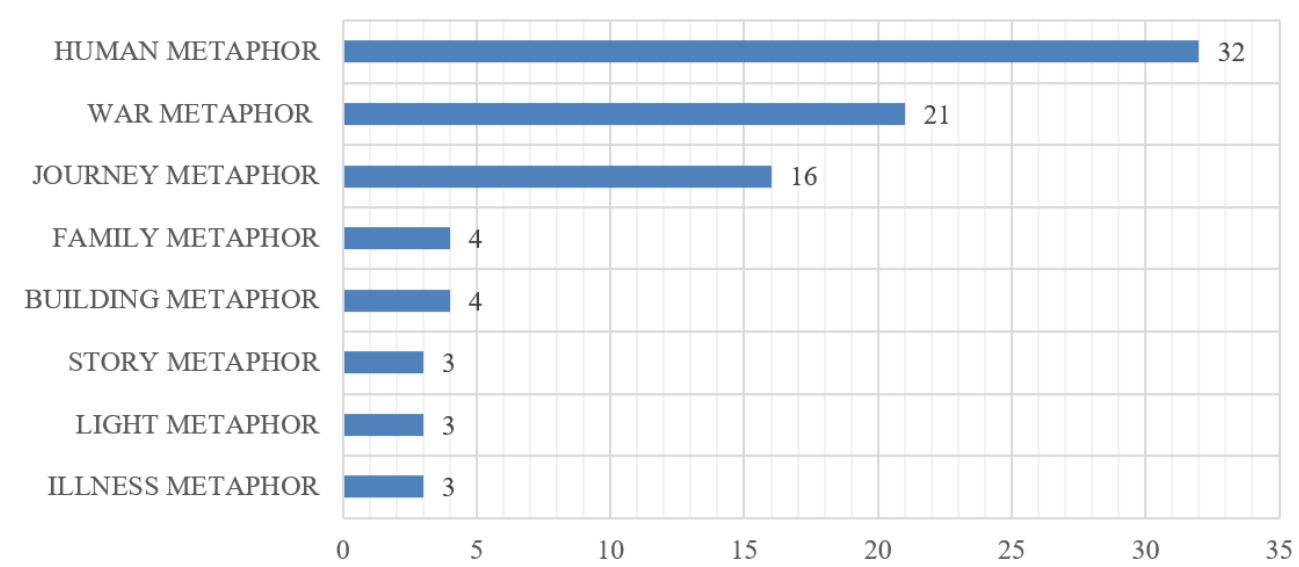

Figure 4.1 Types of Conceptual Metaphors in President Muhammadu Buhari’s political rhetoric

These findings are, to some extent, close to Pasaribu's (2016) findings on metaphors in Joko Widodo's political speeches, where the researcher also reported that HUMAN metaphors, WAR metaphors and JOURNEY metaphors are preponderant in Widodo's speeches. However, Pasaribu additionally observes that Widodo also uses NAVIGATION metaphors to conceptualize himself as the chief captain of the ship that sails 'through big currents and rolling waves' to reach 'Indonesia Raya' - Great Indonesia. It could be agreeable that this similarity suggests that WAR, HUMAN and JOURNEY metaphors are usually most effectively utilized by politicians, irrespective of culture, to achieve their persuasive goals; while the difference in source domain could be due to the difference in experience and environments/contexts of the speakers and their audience members.

Moreover, from his analysis of metaphors in political speeches of American and British politicians, CharterisBlack (2005) also reports partly corroborating findings to those of the current study. Similar to the current study, Charteris-Black also reports that JOURNEY metaphors and PERSONIFICATIONS are the most dominant metaphors in the data, with Journey metaphors having the highest frequency in American data sub-set and personifications the highest in British data sub-set. This agreement in findings also suggests how politicians effectively utilize Journey metaphors and personifications. However, the current study also discovered high frequency of war metaphors in the political speeches of a Nigerian President. This difference could be culturally and contextually driven because each speaker designs his discourse to a different discourse community with different communicative norms and experience.

In the Nigerian context, for example, both Kamalu and Iniworikabo (2016) and Aremu (2017) corroboratively discover that Nigerian political presidents mostly use war metaphors and Journey metaphor in their political speeches. This similarity in findings could be attributable to similarities in culture and political context, as all 
studies that investigated Nigerian Presidents revealed. However, it can also be seen that the current study additionally discovers human metaphors among the most frequently used metaphors by President Buhari in his speeches. This difference could be assumed to have resulted from difference in political ideologies and party policies. Both Kamalu and Iniworikabo and Aremu analyzed political speeches produced by multiple Nigerian presidents of the same party -PDP, while the current study focused specifically on a single Nigerian President of a different political party - APC.

In conclusion, the current study has discovered that Nigeria's President Muhammadu Buhari mostly uses HUMAN metaphors, WAR metaphors and JOURNEY metaphors in his political rhetoric. It has been shown how these findings are consistent with the findings of other previous metaphor studies in different presidential political speeches. In addition, it has also been shown how partly inconsistent the findings of the current study are, even with those of other studies in the Nigerian context. Divergences in findings have been attributed to not only methodology, culture, context and political ideologies but also political party policies. The next section explores the rhetorical functions of the metaphor identified.

\subsection{Rhetorical Functions of Conceptual Metaphors Deployed in President Muhammadu Buhari's Political Rhetoric Perform}

The second phase of analysis in this study discovered that the conceptual metaphors in President Muhammadu Buhari's Political rhetoric mostly establish his ethical integrity, heighten emotional impact and also communicate his political ideologies. The most preponderant types of metaphors in his speeches - HUMAN metaphors, WAR metaphors and JOURNEY metaphors - are also the most effective in the construction of persuasion in President Muhammadu Buhari's political speeches. These metaphors are explained and illustrated as follows:

\subsubsection{Human Metaphor}

Also called personification, this is a special type of ontological metaphor where human attributes are mapped on to inanimate entities. In political discourse, mostly, abstract political phenomena such as the nation and the economy are often described in terms or human activities, characteristics and motivations. The analysis revealed that President Muhammadu Buhari's in his political speeches mostly uses the conceptual metaphor THE NATION IS A PERSON. He mostly personifies Nigeria and gives it human qualities. The following examples illustrate this finding:

\section{Example 1}

'... For the past six years, Nigeria has walked backwards carrying the weight of PDP's incompetence on its shoulders ... [she] has been afflicted by a strange illness. We are a great nation riddled by endless crises. Instead of resolving problems, this government multiplies and manufactures them ... it's now time for change...'

(President Buhari, Presidential Primaries Speech, December 10 $0^{\text {th }}, 2014$ )

\section{Example 2}

'... I see [my nomination] as a tribute and mark of confidence to carry the torch as we all join hands to rescue our dear country Nigeria, from those who have led us into the current state of insecurity, poverty, sectarian divide and hopelessness among our people. I ... ask ... you [to] join me in a common cause [of] love for our nation and concern for its present condition. And a resolve to make things better for Nigeria...'

(President Buhari, Acceptance Speech, December 11 $1^{\text {th }}, 2014$ )

\section{Example 3}

'... I thank the people of Nigeria for reposing their confidence in me at this trying moment. Our nation wrestles many challenges including insecurity, corruption, and economic decline. I pledge to give you my best in tackling these problems... this nation has suffered greatly in the recent past, and its staying power has been tested to its limits by crises, chief among which is insurgency of the Boko Haram ...'

(President Buhari, Victory Speech, April 1 ${ }^{\text {st }}, 2015$ )

It can be seen from the excerpts in examples 1 to 3 above that the president personifies Nigeria as a person who is being troubled and needs to be rescued from the avoidable and unnecessary woes. He depicts the nation as 'feebly walked backwards carrying weight of incompetence on its shoulders', who has also been 'afflicted by a strange illness'. This metaphor conveys the sad message that Nigeria is not well, things are very wrong and there is need for urgent remedy, which is supporting him to change the incumbent government. In example 2, the president also calls on his fellow citizens (the audience) to 'join hands' with him to 'rescue' the nation for their 'love and concern for its present condition'. This metaphor is a self-legitimization strategy intended to enhance Buhari's acceptability 
among the audience. In example 3, the president emphasizes Nigeria's woes by saying the nation 'wrestles many challenges' and also 'suffered greatly in the recent past'. The extent of president Buhari uses those metaphor to establish his ethical integrity and heighten emotional impart

Observed carefully, the president uses simple cognitively accessible terms to portray the extent of Nigeria's woes, the opposition as main cause and proposed solution metaphor. President Muhammadu Buhari uses these metaphors to establish his ethical integrity as someone who can be trusted, who has the country at heart and cares about its condition. He also utilizes these metaphors to arouse the emotions of patriotism and determination to change the current government for better. These metaphors are deployed also as delegitimization strategies by the president because they have represented the opposition as responsible for the then Nigeria's predicament.

These metaphors would convey vividly to the audience the deplorable state of the Nigeria's situation, demonize the then incumbent government and represent it as responsible for whatever is going wrong, and then represent Buhari as the legitimate source of authority, the one with the right intentions. Furthermore, by identifying with them in terms of Nigeria's crises and the way forward, Buhari is establishing a common bond between himself and the audience. This is a credibility-building strategy that has the potential to enhance his character credibility, engage the audience in his speeches and ultimately persuade them.

Therefore, President Buhari, in his political rhetoric, utilizes HUMAN metaphor to establish his ethical integrity by building his character credibility through common-bond technique and delegitimizing opponents, and also heightening emotional impact through his appeal to patriotic emotions among the audience. The president expresses concern about the Nigeria's crises, which he argues to have been 'manufactured' and 'multiplied' by the current opposition government under PDP. This is a strategy to show that he truly shares, with the audience, the predicaments being faced, and also to represent the current government as demons who do not deserve to be voted for again. He therefore asks the audience to, out of patriotism, support him in 'rescuing' the country.

In conclusion, the current study's findings on human metaphor partly agree with those of Pasaribu (2016) and Xu (2010) who have also reported that political leaders utilize this metaphor for simplifying their political messages and persuading their audience. However, the current study additionally observed that President Buhari also uses this metaphor to create common bond between himself and the audience, and also to delegitimize his opponents and consequently establish his ethical integrity and heighten emotional impact.

\subsubsection{War Metaphor}

War metaphor, in the domain of political discourse, is where a political orator employs words and phrases from the domain of war to talk about political phenomena or issues. It is the use of the conceptual metaphor POLITICS IS WAR in political speeches. The analysis of the current study revealed that President Muhammadu Buhari uses WAR metaphor much more frequently in his political rhetoric. In these metaphors, Buhari presents himself as the commander-in-chief who will lead the war against one of Nigeria's mortal enemies - corruption. The president conceptualizes corruption as the worst enemy he desires to fight and completely destroy in Nigeria. Examples from the speeches include:

\section{Example 4}

'... When I last led this nation, I launched a War against Indiscipline - today, I pledge a Battle for Hope, a battle against the dark forces of corruption and despair that have held our nation hostage to their greed for too long. We simply cannot afford four more years of PDP's corruption ...'

(President Buhari, Presidential Primaries Speech, December $10^{\text {th }}, 2014$ )

\section{Example 5}

'... We will strive to attack poverty through broadly-shared economic growth and attacking corruption through impartial application of the law...'

(President Buhari, Acceptance Speech, December 11 $\left.{ }^{\text {th }}, 2014\right)$

\section{Example 6}

'... we shall strongly battle another form of evil that is even worse than terrorism-the evil of corruption. Corruption attacks and seeks to destroy our national institutions and character. By misdirecting into selfish hands funds intended for the public purpose, corruption distorts the economy and worsens income inequality. It creates a class of unjustly-enriched people ...'

(President Buhari, Victory Speech, April 1 ${ }^{\text {st }}, 2015$ ) 
As seen from the excepts above, President Buhari uses war metaphor to represent himself as the commander leading his team to fight Nigeria's most deadly enemy - corruption - under the People's Democratic Party (PDP). Given the Nigeria's situation at the time of presenting these speeches, these metaphors would certainly endear Buhari to most Nigerians because they would promise remedies to their predicaments. Most Nigerians believed that the high level of poverty, youth unemployment, insecurity, insurgency and bad economy being experienced were all attributable to the high level of corruption in the country. Consequently, most Nigerians were supporting President Buhari because of his historic incorruptibility and usual fierce anti-corruption stance. Therefore, it could be argued that these metaphors are very effective strategies in enhancing Buhari's credibility among his political audience. They would afford him the ability to establish rapport with the audience because he is talking about their mutual concerns. This would ultimately establish his ethical integrity as the legitimate source of authority.

Moreover, these metaphors vividly communicate President Buhari's anti-corruption ideology. As highlighted earlier (see 1.1 above), from December 1983 to August 1985, Major General Muhammadu Buhari was Nigeria's military Head of State who recorded tremendous achievements due to his proven honesty, patriotism hard work and rare anti-corruption ideology. During that period, in his effort to cleanse the Nigerian society from the menace of corruption, Buhari launched War Against Indiscipline and Corruption, which was a tremendous success. This anti-corruption ideology of Major General Muhammad Buhari echoes in President Muhammadu Buhari's political rhetoric today. So these metaphors do not only establish Buhari's ethos, they also communicate his anti-corruption ideology. War metaphors are, therefore, effective persuasive devices the president uses to claim legitimacy in his political rhetoric. They are also effective devices for demonizing his appointments - the PDP - who 'misdirect into selfish hands funds intended for public purpose.' This is another strategy for delegitimizing the opponents and claiming legitimacy. Therefore, Buhari utilizes war metaphors to establish his ethical integrity and communicate his anti-corruption ideology.

As shown in these examples, President Buhari employs words and expressions from the domain of war/conflict to talk about his determination to face corruption squarely. Examples of such words from example 4 include war, battle, dark forces, and hostages; while in example 5 the words are attack and attacking. In example 6 he uses battle, attacks, destroy, distorts and worsens. These are highly emotive words and expressions associated with war/conflict. Thing have the inherent potential to evoke emotive feelings in audience and consequently convey mental images of sacrifice, risk-taking heroism and selflessness, which the audience would utilize in conceptualizing the president's level of commitment and sacrifice in handling corruption in the country.

These findings on war metaphors disagree with those of Xu (2010), which emerged from the analysis of inaugural speeches of American presidents. Xu reported that American presidents use war metaphors to motivate the American people to strive hard and sacrifice in tackling poverty, disease and disunity, which are enemies for the attainment of desirable social goals, such as freedom and rights, unity and wealth. This difference could have resulted not only from culture difference between the speakers, but more importantly from the ideology difference and also levels of corruption in the two countries. The level of corruption in American could not be as pronounced as that of Nigeria. However, both the studies suggest that the presidents use war metaphors for persuasive purposes, to be able to ultimately form legitimacy.

\subsubsection{Journey Metaphor}

In the field of political discourse, journey metaphor is where words and expressions from the conceptual domain of journey are employed to talk about issues and phenomena in the domain of politics. Naturally, journeys are always purposeful physical activities and they involve traveler(s), departure points and planned destinations. The conceptual metaphor POLITICS IS A JOURNEY, which entails the metaphor POLITICIANS AND FOLLOWERS ARE TRAVELLERS, has been popular among politicians. Thus, as travelers tussle with impediments, crossroads and traffic jam, political leaders (or nations) and their followers would certainly encounter challenges and difficulties on their way to successful trip. The analysis of the current study discovered that President Buhari deploys journey metaphors in his political rhetoric. However, the results further show that the president (usually) refers to two different journeys in his speeches - (1) the election journey and (2) Nigeria's journey to greatness. These journeys are illustrated and functionally examined in the examples below:

\section{Example 7}

'... Nigerians have shown their commitment to democracy and are determined to entrench its culture. Our journey has not been easy but thanks to the determination of our people and strong support from friends abroad we have today a truly democratically elected government in place ...'

(President Buhari, Presidential Inaugural Speech, May 29th, 2015) 


\section{Example 8}

'... To you all, I pay my absolute compliments and congratulate you on the success of your respective campaigns. I extend my gratitude to you all for accepting the outcome of this convention and agreeing to support my candidature as we move forward... My choice and my colleagues' choice and wish is that we progress together. Preserving the nation's future is a scared obligation to all of us in this party...'

(President Buhari, Acceptance Speech, December 11 ${ }^{\text {th }}, 2014$ )

\section{Example 9}

'... In recent times Nigerian leaders appear to have misread our mission. Our founding fathers ... worked to establish certain standards of governance. They might have differed in their methods or tactics ... but they were united in establishing a viable and progressive country... There is now a national consensus that our chosen route to national development is democracy... Nigeria therefore has a window of opportunity to fulfill our long standing potential of pulling ourselves together and realizing our mission as a great nation...'

(President Buhari, Presidential Inaugural Speech, May 29th, 2015)

The excerpt in example 7, extracted from Buhari's Presidential inaugural speech, shows how the president uses the conceptual metaphor ELECTION IS A JOURNEY, which entails the metaphor THE PRESIDENT AND HIS SUPPORTERS ARE TRAVELLERS. The metaphor is achieved by using the noun phrases 'our journey' and 'determination' to conceptualize the determination, struggles, sacrifice and uncertainties endured by him and his follows in the course of the election campaigns. In this metaphoric journey, the destination is winning the election and changing the incumbent president. That is the main goal.

Functionally examined, the metaphor is used to acknowledge and appreciate the support and contribution of his supporters within and outside Nigeria, whose firm commitment and determination have now led to his success in the elections. This metaphor is strategically deployed at the beginning of the speech to enable the president arouse and sustain the interest and attention of the audience so that they psychologically participate in his speech. The need to be appreciated, as observed Alimole (2004), is one of the subtle human desires and an effective emotional appeal. The president has therefore used this metaphor not only to emotionally connect the audience to his speech, but also to establish his ethical integrity and ultimately form legitimacy.

In example 8, the president is speaking to his in-house opponents and other party members at the convention, after his emergence as the APC presidential candidate. Here too, the president uses expressions such as 'move forward' and 'progress together' with the senses of facing the forthcoming election without division. In this journey, the destination is for the successful candidate - Muhammadu Buhari - and all the party members to keep together, be united in purpose and avoid any division that world jeopardize their predetermined mission of changing the current government. Example 8, therefore, illustrates how Buhari uses metaphor to appeal to the emotions of unity, sacrifice and determination among his party members. It calls upon the party members to have unity of purpose in facing the elections and not be deterred by any other factor. The metaphor, thus, heightens emotional impact, communicates the party's CHANGE ideology, and establishes Buhari's ethical integrity.

Finally, the except in example 9 is taken from Buhari's inaugural address. Key expressions here include: our mission, route and our mission. But unlike the election journey referred to in examples 7 and 8 above which involves President Buhari, in-house opponents and other APC party members only, the journey referred to in example 9 involves President Buhari and all Nigerians irrespective of political parties. It is a journey to Nigeria's greatness, initiated by Nigeria's founding fathers. This journey conceptualizes the proper manner, attitudes, and acts - the chosen route as democracy - that would lead to Nigeria's 'national development' and becoming a 'great nation'. The president uses this metaphor to encourage Nigerians to keep united and determined in embracing clean democracy as a sure way of national development. This metaphor is, therefore, used to heighten the emotional impact of patriotism, unity, and selfless service among Nigerians. It would also establish Buhari's ethical integrity because the audience would perceive him as a concerned, patriotic Nigerian.

In a nutshell, this study has revealed how President Buhari uses two types of journey metaphor with two different functions. He uses (1) election journey metaphor and (2) Nigeria's journey to greatness metaphor. While the (1) election journey metaphor is used to acknowledge and appreciate his supporters' sacrifice and contribution to his success in the elections, or to call for unity of purpose and firm determination among his party members in facing the election; (2) Nigeria Nigeria's journey to greatness metaphor is used to encourage unity and selfless service among Nigerians for the good of the nation. These findings corroborate Charteris-Black's (2005) and Xu's (2010) findings that political orators utilize journey metaphors to enable their follows to have clear predetermined 
objectives in mind and always be united in pursuing them. However, the current study also discovers how President Buhari utilizes journey metaphors for expressing acknowledgement and appreciation to his supporters.

\subsubsection{Family Metaphor}

In family metaphors, words and expressions from the conceptual domain of family are used in talking about issues or phenomena in another conceptual domain. In the domain of political discourse, politicians often utilize this metaphor to achieve the conceptual metaphor NATION IS A FAMILY, which entails THE LEADER IS A PARENT and THE CITIZENS ARE CHILDREN. Analysis of the current study discovers that although its frequency is relatively low, President Buhari in his political rhetoric uses this metaphor. Example 10 below illustrates the use of family metaphor in Buhari's acceptance speech:

\section{Example 10}

'... Shall we continue in a situation where 250 of our daughters have been abducted and the government has been unable to rescue them or provide credible information about what steps they are taking?'

(President Buhari, acceptance speech, December 11 $1^{\text {th }}, 2014$ )

The President uses this metaphor in a series of rhetorical questions he asks with the aim of emphasizing areas of weakness and incompetence of the incumbent government - power outage, Chibok girls' abduction by Boko Haram insurgents in Borno State, youth unemployment, and corruption. As signaled by the words 'our daughters' used in the except, the president specifically uses this metaphor to refer to Chibok girls' abduction as a huge government failure that should not be allowed to continue. He delegalizes the current government and calls for its change. The present suggest in his metaphor that the government has not been able to rescue the 250 girls abducted, and have still not put any serious measures in place to that effect.

Therefore, rhetorically examined, this metaphor performs 3 key functions in Buhari's rhetoric. Firstly, it establishes his ethical integrity by enabling the president to identify with the concerns of the audience. He sees the abducted girls as his daughters too. He is impliedly as disturbed as the girls' biological parents. Secondly, this metaphor would also heighten emotional impact, especially the emotions of sympathy for the girls and their parents, and also concern for human lives. Thirdly, the metaphor also demonizes the current government and ultimately communicates the CHANGE ideology of his party.

The findings of this study on family metaphor in Nigerian political rhetoric contrast with those of Kamalu \& IniworiKabo (2016) and Aremu (2017). Kamalu and Iniworikabo's and Aremu's studies both reported that Nigeria's Presidents in their political discourse utilize family metaphors to preach unity among Nigerians. However, the current study discovered that President Buhari uses family metaphor to establish his ethos, heighten emotions (of sympathy and concern), and also communicate his party's change ideology. This difference is, perhaps, owing to difference in the frameworks of analysis applied in the studies, and also style differences between the politicians analyzed.

\subsubsection{Building Metaphor}

Using building metaphor means employing words and phrases from the domain of building construction to talk about phenomena in other domains. In the domain of political discourse, politicians usually employ this metaphor to portray the conceptual metaphor POLITICIANS ARE NATION BUILDERS, which entails POLITICAL FOLLOWERS ARE LABORERS, and THE NATION IS AN EDIFICE. They represent themselves and their supporters as foundation layers, builders and laborers who construct and re-construct the nation through patriotism, sacrifice and intense struggle (Remanathan et al, 2018). The analysis of the current study discovered that President Buhari also uses this metaphor in his political rhetoric. Example 11 below shows this from Buhari's primary election speech:

\section{Example 11}

'...My love for Nigeria is written large across my heart and I have spent a lifetime in the service of its people. Through a long career trying to build a better country for my fellow Nigerians in offices both high and low, I have always tried to place my country before myself...'

(President Buhari, Presidential Primaries Speech, December 10 $0^{\text {th }}, 2014$ )

The President addressed this speech to 8000 APC delegates at the convention just before casting votes to decide the party's presidential candidate in the fourth-coming general elections. In this metaphor, the president tries to convey the impression of his high degree of patriotism, selfless service and sacrifice in his long career, where he always tirelessly and faithfully served Nigeria for its development. This metaphor could, therefore, have the potential to endear the president to his audience. It would enable him to sound as someone who always has the 
power of right intentions and also someone who ideologically believes in selfless service and sacrifice to his motherland. Consequently, the delegates would be persuaded that he is the best choice they could make in their attempt to save Nigeria from its current crises of corruption, poverty, unemployment, insecurity and bad economy.

Observed carefully, it could be argued that the findings of the current study are, to some extent, consisted with those of Lu and Ahrens (2008), who reported that Taiwanese Presidents use building metaphors to communicate their political ideologies. The current study too has discovered how President Buhari utilizes building metaphor to convey his ideology of selfless service and sacrifice for the betterment of his country. Furthermore, these findings also partially corroborate those of Ramanathan et al (2018) on election tweets of Najib and Modi, which reported that both the Prime Ministers utilize building metaphors to motivate and persuade Malaysians and Indians (respectively) to vote for them during the elections. Similarly, in the current study, President Buhari uses the building metaphor to establish his ethical integrity through revealing his rare positive virtues that would certainly persuade the delegates to cast their votes in his favor. However, Kamalu and Iniworikabo's (2016) findings contrast with the current findings because the researchers observed that all of President Obasanjo, President Yar'adua and President Jonathan use building metaphors to preach unity among Nigerians despite the multi-ethnic and multireligious nature of the nation. Therefore, the politicians are all using the metaphor to form legitimacy and persuade their audience that they are legitimate sources of authority.

\subsubsection{Illness Metaphor}

Illness metaphor involves the use of words and expressions that convey images of illness and restoration or healing in discussing conceptual domains that are inanimate, abstract, or even complicated for the audience to cognitively access the messages. In the domain of political discourse, politicians often argue that as persons' health conditions deteriorate and they fall sick, nations too can suffer deteriorating health conditions, and they can be ravaged by ailments such as insecurity, corruption, disunity, poverty, insurgency and so on. They represent themselves as physicians who have the required skills and tools for nurturing and restoring the nations' good health. The analysis of the current study revealed that President Buhari also uses Illness metaphor in his political rhetoric. Example 12 below illustrates this from his Primaries Speech:

\section{Example 12}

'Due to its broken leadership, Nigeria has been afflicted by a strange illness. We are a great nation riddled by endless crises. Instead of resolving problems, this government multiplies and manufactures them... things have only gotten worse [under PDP] ... it's now time for change. What we need now is change!'

(President Buhari, Presidential Primaries Speech, December 10 $0^{\text {th }}, 2014$ )

In this metaphor, President Buhari laments that Nigeria has been 'afflicted' by a 'strange illness'. He goes ahead, in the second sentence, to specifically mention 'crises' - the insecurity, unemployment, poverty and corruption which he subsequently argues were 'manufactured' and 'multiplied' by the incumbent PDP government, which deserves to be changed. According to the president, in this metaphor, the only solution to the woes being faced in Nigeria at that moment is changing the incumbent government.

Examined functionally, therefore, this metaphor was used by the President to establish his ethical integrity, communicate political argument, and ideology. Firstly, the metaphor establishes the president's ethical integrity because he seems to have been affected by the crises Nigerians experience, and he is determined to end them. This credibility-building strategy would enhance the president's acceptance among the audience because he sincerely shares their concerns. Secondly, the metaphor communicates political arguments because the president uses it to intensify Nigeria's crises and demonize his opponents as not only causative agents but are also multipliers of the crises - how the poor leadership of PDP has ruined the country. Thirdly, the metaphor in a form of call-to-action technique meant to motivate the audience to contribute towards change. It obviously communicates Buhari's change ideology. He calls on the audience to work towards changing the government as the only solution to their current challenges.

The findings of this study on illness metaphor disagree with those of Kamalu and IniworiKabo (2016), to some extent. Kamalu and IniworiKabo, who investigated political speeches of former Nigerian Presidents - Obasanjo, Yar'adu and Jonathan - reported that the presidents use illness metaphors in making pledges, promising and undertaking to 'heal divisions', 'ease the pains' and resuscitate unity among Nigeria's multi-ethnic and multireligious population. This difference could have resulted from party policies, priorities and ideologies as all the politicians analyzed by Kamalu and IniworiKabo belong to the PDP, while Muhammadu Buhari belongs to the APC. It may also have resulted from the difference in research approach, especially regarding framework of 
analysis. However, both studies have been consistent that the Presidents use illness metaphor for rhetorical purpose of persuasion, to be able to convince the audience that they can be trusted.

\subsubsection{Story Metaphor}

As discussed by Lakoff and Johnson (1980: 172 - 175), the metaphor LIFE IS A STORY is based on the assumption that everyone's life is structured like a story, which can be constructed as a coherent narrative that starts at some point and ends at another point. Like most narratives, it will have some or all of: characters, parts, stages, linear sequence, causation and purpose. Therefore, to fully understand or appreciate one's life in terms of a coherent life story involves highlighting certain characters and parts, seeing the life in terms of stages, causal connections and so on in order to achieve a goal or set of goals. In the domain of political discourse, politicians personify nations and represent themselves as characters or participants that would positively impact on the entire life story of the nations by effecting positive changes at particular parts and stages. For instance, example 13 below shows how President Buhari uses this metaphor in his acceptance speech:

\section{Example 13}

'... My answers to these questions are "No, No, No, No!" It is time to close this demeaning chapter in our nation's history. I ask that you join this effort, not for me, but to establish a better land for all of us...'

(President Buhari, acceptance speech, December 11 $11^{\text {th }}, 2014$ )

President Buhari uses this metaphor after a series of rhetorical questions asked as to whether he and the audience should fold their arms and watch Nigeria battling with problems of power outage, abduction of 250 Chibok girls by the Boko Haram insurgents, unemployment, poverty and corruption. It is a kind of wake-up call, a strategy to inspire the audience to take part in rescuing the nation from all these crises by supporting him to change the incumbent government. He urges them to 'close this demeaning chapter in our nation's history'. This metaphor is used as a persuasive device by the president. It is a self-legitimization strategy that would also evoke emotive feelings among the audience and move them to action.

In a nutshell, this metaphor establishes Buhari's ethical integrity by projecting his common ground with the audience, and also for evoking emotional responses from the audience. It will arouse feelings of patriotism among the audience and inspire them to act towards restoring the nation's happiness. The story metaphor is therefore a valuable technique for self-legitimization and infecting the minds of the audience. However, most studies on conceptual metaphor do not focus much attention on it.

\subsubsection{Light Metaphor}

Political leaders often employ words and expressions from the conceptual domain of light, day and night or darkness in talking about political issues. This conceptual mapping enhances their rhetoric by, for example, simplifying cognitive accessibility of their messages, and also for intensifying emotions (as Biden conceptualized his contest for the White House in 2020 with President Trump as a fight between light and darkness). In the current study, for example, President Buhari uses light metaphor in his victory speech to excite and inspire his audience. This is shown in example 14 below:

\section{Example 14}

'... Our long night has passed and the daylight of new democratic governance has broken across the land. This therefore is not a victory for one man or even one party. It is a victory for Nigeria and for all Nigerians. Millions of you have worked for this day...'

(President Buhari, Victory Speech, April 1 ${ }^{\text {st }}, 2015$ )

This metaphor was used in a speech immediately after the official announcement of Muhammadu Buhari's victory as the newly elected President of the Federal Republic of Nigeria. The president-elect utilizes the metaphor to excite and inspire the audience. It would go a long way in managing his positive impression and undermining the resistance and criticism of the opposition. The contrasting expressions 'long night' and 'daylight' used in this metaphor intensify the degree of relief or success conveyed in the President's message. His assertion that the victory is not just for one man or one party, but for all Nigerians would enhance his acceptability even among the opposition. Therefore, this metaphor functions as a rhetorical device in this speech for establishing the president's ethical integrity by enhancing his acceptability, and also for heightening emotional impact among the audience. It would ultimately enable him to persuade the audience and also manage impressions. 


\section{Conclusions}

This study was an attempt to investigate the use of conceptual metaphors in President Muhammadu Buhari's political rhetoric. Drawing on Lakoff and Johnson's (1980) Conceptual Metaphor Theory (CMT), the study utilized Charteris-Black's (2009) contemporary framework of metaphor and political communication. The analysis revealed that the most preponderant types of metaphor in President Buhari's political speeches include: HUMAN metaphors, WAR metaphors, and JOURNEY metaphors; while the least used metaphors in the speeches include: FAMILY metaphors, BUILDING metaphors, ILLNESS metaphors, LIGHT metaphors and STORY metaphors. These findings were partly attributed to the president's desire to employ everyday terms that are familiar and cognitively accessible to his audience so that his political messages were well understood. The findings were also partly attributed to the president's military background, especially the frequent use of WAR metaphors.

On the other hand, analysis of rhetorical functions of these metaphors discovered that President Buhari deployed them mainly for establishing his ethical integrity, heightening emotional impact, and communicating his anticorruption and political ideologies. The president established his ethical integrity through the use of metaphors by identifying with the concerns of his audience on Nigeria's crises (Boko Haram insurgency, insecurity, power outage, unemployment and bad economy), demonizing his opponents as manufacturers and multipliers of these crises, and by legitimizing and presenting himself as having the power of right intentions and determination to save the situation if elected into the presidential office. The president heightened the emotional impact through the use of metaphors by utilizing metaphors to appeal to the audience's senses of patriotism, sacrifice, selfless service and hard work as he urged them to work with him in rescuing Nigeria. Buhari communicated his anti-corruption ideologies through metaphors, especially by deploying WAR metaphors, that depict corruption as Nigeria's mortal enemy and represent him as the commander-in-chief leading the army.

Moreover, from the foregoing, it could be understood that President Buhari's political metaphors have been so powerfully persuasive that they enabled him to form legitimacy among his audience. The metaphors obviously had the potential to convince Buhari's audience that he was the only legitimate source of authority, whom they should support to rescue Nigeria from its current crises, and for a good future. The president has therefore, like other political leaders, employed metaphors as vital rhetorical tools strategically utilized for self-legitimization, delegitimizing opponents, and claiming authority.

Finally, it could be assumed that this study would extend the current state of knowledge on the interactionability between conceptual metaphors and political leaders' persuasive intentions. It could also broaden the body of literature on metaphors in political discourse, which would ultimately benefit the academia - scholars, researchers, and students.

\section{Reference}

Alimole, O. (2004). Speaking to Win: An Introduction to The Art of Public Speaking. Ibadan: Heinemann Educational Books Nigeria Plc.

Aremu, M. (2017). Pragmatic Analysis of Conceptual Mappings in Inaugural Speeches of Nigerian Presidents. Covenant Journal of Language Studies, 5(2).

Bornstein, R. F., \& Becker-Matero, N. (2011). Reconnecting psychoanalysis to mainstream psychology: Metaphor as glue. Psychoanalytic Inquiry, 31, 172-184, 2011. https://doi.org/10.1080/07351690.2010.515874

Charteris-Black, J. (2005/2011). Politicians and rhetoric: The persuasive power of metaphor. New York: Palgrave Macmillan. https://doi.org/10.1057/9780230501706

Charteris-Black, J. (2009). Metaphor and political communication. In Metaphor and discourse (pp. 97-115). Palgrave Macmillan, London. https://doi.org/10.1057/9780230594647_7

Charteris-Black, J. (2009). Metaphor and political communication. (eds) in Musolff, A., \& Zinken, J. (Eds.). (2009). Metaphor and discourse (pp. 233-247). Basingstoke/New York: Palgrave Macmillan. https://doi.org/10.1057/9780230594647_7

Chilton, P. (2004). Analysing political discourse: Theory and practice. Routledge. https://doi.org/10.4324/9780203561218

Creswell, J. W. (2012). Education research: planning, conducting and evaluating quantitative and qualitative research. Boston/New York: Pearson

Dörnyei, Z. (2007). Research methods in applied linguistics: Quantitative, qualitative, and mixed methodologies. Oxford University Press. 
Escudero, M. P. G. (2011). Barack Obama's inaugural address: Metaphor and values as captivating strategies to celebrate a presidency. Pragmalingüística, $\quad$ (19), https://doi.org/10.25267/Pragmalinguistica.2011.i19.03

$\mathrm{Hu}, \mathrm{X}$. (2010). A study on conceptual metaphors in presidential inaugural speeches. (eds) in School of Teacher Education, Kristianstad University.

Jeffery, M., \& Albert, N. K. (1996). Metaphor: Implications and Applications. New Jersey: Lawrence Erlbaum Associations Publishers.

Jones, R. H. (2012). Discourse analysis. London and New York: Routledge.

Kamalu, I., \& Iniworikabo, P. B. (2016). Metaphors in selected political speeches of Nigerian democratic presidents. California Linguistic Notes, 40(2), 71-84.

Kovecses, Z. (2002). Metaphor: A Practical introduction. Oxford: Oxford University Press.

Lakoff, G., \& M, Johnson (1980). Metaphors We Live By. Chicago: Chicago University Press.

Linkevičiūte, V. (2019). Conceptual metaphors in Donald Trump's political discourse: Politics Domain (2018). Kalbu Studijos, (34), 46-55. https://doi.org/10.5755/j01.sal.34.0.21886

Lu, L. W. L., \& Ahrens, K. (2008). Ideological influence on BUILDING metaphors in Taiwanese presidential speeches. Discourse \& Society, 19(3), 383-408. https://doi.org/10.1177/0957926508088966

Malah, Z. (2016). Signals from the Surface of Texts: How Lexical Cohesion Reflects Writers' Tones in Nigerian Newspaper Editorials. International Journal Language and Linguistics, 3.

Malah, Z., \& Idriss, A. (2016). Sociolinguistic Exploration of Nigerians' Political WhatsApp Communities: A Case Study of President Muhammadu Buhari Supporters' groups. Research Journal of English Language and Literature, 4(4), 560-572.

Matthews, B., \& Ross, L. (2010). Research methods. Pearson Higher Ed.

McGlone, M. S. (1996). Conceptual metaphors and figurative language interpretation: Food for Thought? Journal of memory and language, 35(4), 544-565. https://doi.org/10.1006/jmla.1996.0029

Merriam, S. B., \& Tisdell, E. J. (2009). Qualitative research: A guide to design and implementation. John Wiley \& Sons.

Mio, J. S., Riggio, R. E., Levin, S., \& Reese, R. (2005). Presidential leadership and charisma: The effects of metaphor. The Leadership Quarterly, 16(2), 287-294. https://doi.org/10.1016/j.leaqua.2005.01.005

Moser, K. S. (2000, June). Metaphor analysis in psychology-Method, theory, and fields of application. In Forum Qualitative Sozialforschung/Forum: Qualitative Social Research (Vol. 1, No. 2).

Musolff, A. (2004). Metaphor and political discourse. Analogical Reasoning in Debates about Europe. Basingstoke, 14. https://doi.org/10.1057/9780230504516

Pasaribu, T. A. (2016). Domains of political metaphors in presidential speeches. LLT Journal: A Journal on Language and Language Teaching, 19(2), 96-104.

Prados, M. D., \& Peñuelas, A. B. C. (2012). Cohesion in American political rhetoric: The Gettysburg Address, I have a dream and Obama's Inaugural Address/La cohesión en la retórica política americana: Los discursos Gettysburg Address, I have a dream y el de la Investidura de Obama. Complutense Journal of English Studies, 20,37. https://doi.org/10.5209/rev_EIUC. 2012.v20.39994

Ramanathan, R., Hoon, T. B., \& Paramasivam, S. (2018). Metaphors in Political Tweets during National Elections. Pertanika Journal of Social Sciences \& Humanities, 26(2).

Semino, E. (2008). Metaphor in discourse. Cambridge: Cambridge University Press.

Tavakoli, H. (2010). A dictionary of research methodology and statistics in applied linguistics. Tehran:Rahnama press.

Verbrugge, R. R., \& McCarrell, N. S. (1977). Metaphoric comprehension: Studies in reminding and resembling. Cognitive psychology, 9(4), 494-533. https://doi.org/10.1016/0010-0285(77)90018-4

Wilson, D. (1994). Language and Understanding. Oxford: Oxford University Press.

Wodak, R. (2009). The discourse of politics in action: Politics as usual. Springer. https://doi.org/10.1057/9780230233683 
Xue, J., Mao, Z., \& Li, N. (2013). Conceptual metaphor in American presidential inaugural addresses. Theory and Practice in Language Studies, 3(4), 678. https://doi.org/10.4304/tpls.3.4.678-683

\section{Copyrights}

Copyright for this article is retained by the author(s), with first publication rights granted to the journal.

This is an open-access article distributed under the terms and conditions of the Creative Commons Attribution license (http://creativecommons.org/licenses/by/4.0/). 